\title{
United States: Publication of Financial Sector Assessment Program Documentation- Technical Note on Consolidated Regulation and Supervision
}

This paper was prepared based on the information available at the time it was completed on July 23, 2010. The views expressed in this document are those of the staff team and do not necessarily reflect the views of the government of the United States or the Executive Board of the IMF.

The policy of publication of staff reports and other documents by the IMF allows for the deletion of market-sensitive information.

Copies of this report are available to the public from

International Monetary Fund • Publication Services

700 19th Street, N.W. • Washington, D.C. 20431

Telephone: (202) 623-7430 • Telefax: (202) 623-7201

E-mail: publications@imf.org • Internet: http://www.imf.org

\section{International Monetary Fund Washington, D.C.}


FinANCIAL SECTOR ASSESSMENT PROGRAM UNITED STATES OF AMERICA

CONSOLIDATED REGULATION AND SUPERVISION TECHNICAL NOTE

JULY 2010 



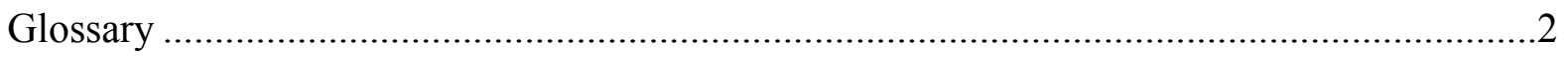

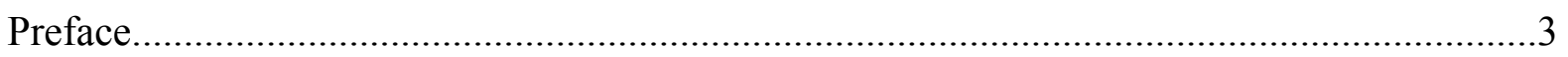

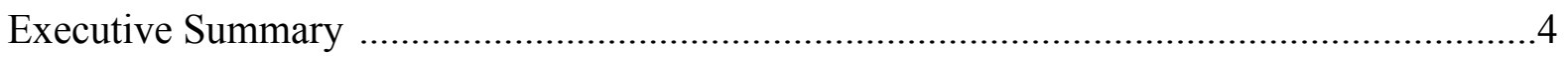

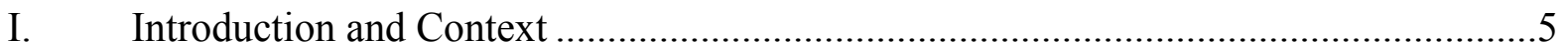

II. Regulation, System Structure, and the Role of Conglomerates...................................5

III. U.S. Consolidated Regulatory and Supervisory Arrangements .................................9

IV. Outcomes, Reform Proposals, and Risks ...................................................... 12

V. Recommendations and Conclusion .......................................................................... 14

Text Boxes

1. United States: Key FSAP Recommendations on Consolidated Oversight ...................4

Appendix Tables

1. United States: Key Financial Stability Proposals and Outcomes .............................16 


\section{GLOSSARY}

ABS

AIG

BoA

BHC

BHCA

CFTC

Citi

CSE

DPC

FCM

FDIC

Fed

FHC

FSAP

FSOC

GAO

GE

GLBA

GSE

ILC

IMF

JPM

MMF

NCUA

OCC

OTS

QFC

SBD

SEC

SIBHC

SIV

SLHC

SSHC

t1FHC

WaMu
Asset backed security

Amercan International Group, Inc.

Bank of America Corporation

Banking holding company

Bank Holding Company Act of 1956

Commodity Futures Trading Commission

Citigroup Inc.

Consolidated supervised entity

Derivative product company

Futures commission merchant

Federal Deposit Insurance Corporation

Federal Reserve

Financial holding company

Financial Sector Assessment Program

Financial Stability Oversight Council

Government Accountability Office

General Electric Company

Gramm-Leach-Bliley Act of 1999

(also known as the Financial Services Modernization Act)

Government sponsored enterprise

Industrial loan company

International Monetary Fund

JPMorgan Chase \& Co.

Money market fund (as defined by Rule $2 \mathrm{a}-7$ of the

Investment Company Act of 1940; hence also known as "2a-7 fund")

National Credit Union Administration

Office of the Comptroller of the Currency

Office of Thrift Supervision

Qualified financial contract

Securities broker-dealer

Securities and Exchange Commission

Supervised investment bank holding company

Structured investment vehicle

Savings and loan holding company

Supervised securities holding company

Tier 1 financial holding company

Washington Mutual, Inc. 


\section{Preface}

This technical note was prepared as part of the Financial Sector Assessment Program (FSAP) exercise for the United States. The FSAP involved two sets of meetings, during October 14-November 3, 2009 and February 17-March 12, 2010. Interlocutors included senior officials of the U.S. Department of the Treasury, the Federal Reserve (Fed), the Office of the Comptroller of Currency, the Federal Deposit Insurance Corporation (FDIC), the Office of Thrift Supervision (OTS), the Securities and Exchange Commission (SEC), the Commodity Futures Trading Commission (CFTC), and the Federal Housing Finance Agency. This note has benefited from discussions with and comments from all of these bodies.

The recommendations in this note, and in the U.S. FSAP assessment more generally, are perhaps somewhat more specific than in other assessments. To be sure, legal frameworks, regulatory arrangements, and financial system structures vary greatly across countries, and no one model has proven decidedly superior, not least in the recent crisis. Nonetheless, the far-reaching U.S. legislative effort, and concerns about regulatory complexity - a recurring theme in the assessments of U.S. observance of international regulatory standards - argued against agnosticism on the organization of regulation and supervision in this instance.

Importantly, in addition to issues regarding the regulatory and supervisory architecture, basic prerequisites will need to be tackled to maximize effectiveness. As emphasized in the FSAP's Financial System Stability Assessment (imf.org) and Reports on the Observance of Standards and Codes (imf.org), the critical need is for high-quality information-sharing, coordination, systemic risk analysis, accountability, and clarity of mandates. Changes to the U.S. regulatory architecture, including along the lines suggested in this note, could help, but would of course not be sufficient.

Finally, this note was finalized as the Dodd-Frank Wall Street Reform and Consumer Protection Act of 2010 was signed by the President. With the Act amending many of the laws discussed below, the focus herein is on incumbent regulatory arrangements, many of which will change. Every effort is made to capture the essence of the reform legislation, but not all details can be or are covered. 


\section{EXECUTIVE SUMMARY ${ }^{1}$}

This note reviews outgoing U.S. consolidated regulatory and supervisory arrangements and explores (what were) some options to strengthen them (Box 1). Group-level regulation and supervision are arguably the most potent tools of financial sector oversight. Their emphasis on enterprise-wide risk management mirrors how many financial firms are run in practice. Thus they are key instruments with which to mitigate systemic risk.

Although U.S. consolidated regulation and supervision span from the smallest financial groups to the largest and most complex, much effort is focused on the latter. The crisis has underscored how a very significant share of the financial system is controlled by a few key holding companies. The few "mega-diversified" conglomerates are both heterogeneous and systemic, posing an enormous — and critical—supervisory challenge.

This note addresses the basic statutory arrangements for consolidated regulation and supervision, as distinct from the actual exercise of such oversight. In essence, the changes needed are (or were) threefold: to eliminate exceptions for holding companies owning certain limited-purpose banks; to harmonize arrangements for bank and thrift holding companies; and to bring into the net a few systemic nonbank holding companies.

One message to stress up-front is that, of all the U.S. regulatory bodies, it is the Fed that is best placed to bear the consolidated supervisory mandate. Nonetheless, it too will need to reallocate resources, to some extent, from the banking to the securities and other nonbanking operations of the large complex conglomerates that it oversees.

\section{Box 1. United States: Key FSAP Recommendations on Consolidated Oversight}

- Organization and location: Establish one, and only one, federal program of consolidated regulation and supervision, grounded in statute and housed at the Fed.

- Scope: Cover in this program all holding companies that own one or more FDIC-insured depository institutions, regardless of charter type and without exception, plus any other financial firms deemed to be potentially systemic, through selection procedures to be established.

- Mandate: Give this program the dual mandate of supporting the safety and soundness of the covered groups individually and mitigating any systemic risk they may create collectively.

- Activity restrictions: Prohibit covered groups from engaging in most commercial activities, and require the Fed to enforce such prohibitions.

- Prudential norms: Require the Fed, through this program, to impose and enforce prudential requirements at the consolidated level, with a system of mandatory supervisory actions, and to subject the largest and most interconnected of the covered groups to stricter standards.

- Deference: Authorize the Fed, through this program, to impose additional requirements on any regulated or unregulated subsidiary, with due attention to regulatory differences by type of firm, softening but not eliminating deference requirements vis-à-vis bank and functional regulators.

- Additional enforcement powers: Vest the Fed, through this program, with additional, discretionary enforcement authorities, up to and including orders to divest business lines or subsidiaries.

\footnotetext{
${ }^{1}$ Prepared by Ashok Vir Bhatia (IMF, Strategy, Policy and Review Department); July 22, 2010.
} 


\section{INTRODUCTION AND CONTEXT}

1. Regulatory and supervisory failures and gaps rank high among the causes of the global financial crisis of 2007-09. This is now widely accepted, not least by the U.S. Administration, the Congress, the Fed, and the financial regulatory agencies.

2. Reforms to financial regulation and supervision thus form a major part of the post-crisis policy response. Building on detailed proposals and legislative language tabled by the Administration in 2009, the Congress has just passed, and President Obama has just signed into law, the Dodd-Frank Wall Street Reform and Consumer Protection Act of 2010. The FSAP team has been supportive of the reform effort, weighing in on priorities and advocating, where merited in its view, for even bolder action.

3. A key focus of the reforms is on arrangements to better mitigate systemic risk. Broadly defined, systemic risk is the risk that the actions of one financial intermediary, or set of similar placed financial intermediaries, will adversely affect others in the system and thence the economy at large — at best, through the formation of macro-significant asset price bubbles in good times; at worst, by triggering asset fire sales and funding panics in crises.

4. The Congress has established a Financial Stability Oversight Council (FSOC) to serve as the "systemic risk regulator." Constituted as a council of the Treasury, the Fed, and essentially all of the federal financial regulatory agencies, this FSOC is to be the apex decision-making body on matters of financial stability, with member agencies expected to execute its information-gathering, analytical, supervisory, and regulatory directives.

5. Key to the success of this principle-agent construct will be a strong role for the Fed as "lead executor" of the FSOC. Not only is the Fed uniquely qualified to take on this responsibility, given its monetary policy and lender-of-last-resort duties and associated skill sets, it is also uniquely equipped with the tools needed to execute it, given its consolidated supervisory authorities over bank holding companies (BHCs).

6. With consolidated supervision providing a powerful means of influencing behavior ex ante, the FSAP team views it as a key tool for systemic risk mitigation. The outgoing U.S. regulatory system has had three federal consolidated supervisors: the Fed, the OTS, and the SEC. This note discusses how to strengthen that architecture, concluding - as the Congress has - that there should be only one consolidated supervisor: the Fed.

\section{Regulation, System Structure, AND the Role of Conglomerates}

7. The structure of the U.S. financial system reflects the forces of regulation and taxation on the one hand, and innovation and regulatory arbitrage on the other. In many respects, the basic contours drawn during the Great Depression persist to this day. These include a Congressionally mandated separation of banking from full-scope securities underwriting and commerce, and the notion of retail deposit-taking institutions as a special 
type of firm meriting access to Fed standing facilities and federal deposit insurance- the federal financial safety net - with the attendant moral hazard sought to be offset by especially stringent regulation and supervision, complemented wherever possible by market discipline.

8. The key delivery vehicle for market discipline was and is uninsured funding. The justification for the lighter emphasis on direct supervisory "command and control" of financial intermediaries outside the federal safety net was that they, unlike the commercial banks, savings institutions, and credit unions within, did not benefit directly from government support, and were thus subject to the (harsher) strictures of sophisticated creditors, counterparties, and credit rating agencies, as reflected in the cost and availability of funding. To the extent that depositories chose to supplement their federally insured deposit bases with uninsured funds, they too were viewed as coming under what Chairman Bernanke has called the "invisible hand" of market discipline, as a complement to supervision. Safetyand-soundness oversight was intended to limit — not eliminate - the risk of failure, the specter of which was seen as an essential precondition for the proper functioning of the markets.

\section{As reliance on market funding increased over time, the visible hand of} regulation reached a smaller share of the system. Wholesale funding activity was spurred by many factors, including liberalizations of regulatory policy, advances in technology (notably computers), a quest by financial intermediaries for size and market power, and a search for yield that led many retail savers to choose investments over bank deposits and many intermediaries to choose trading activities over end-user lending. These factors, and an undercurrent of regulatory arbitrage that tended to drive financial business toward less- or unregulated spaces, fuelled rapid growth in derivatives, securitization, and the originate-tosell paradigm, giving rise to a so-called "shadow banking system."

\section{Thus were the lines drawn that shaped the world's most complex financial} sector. As stressed recently by New York Fed President Dudley, the sector truly is a system, bringing together a unique diversity of actors, each type regulated differently, each with its own portfolio preferences. Indeed, it is precisely this heterogeneity that allows transactions to flourish — one side long, the other short, buying, selling, hedging, and price-discovering.

\section{Today, this system can be divided into three broad segments:}

- The government-supported core. This consists of federally insured depository institutions and, with a different set of privileges, the housing government sponsored enterprises (GSEs). These financial firms, together still the most influential in the system, are subject to safety-and-soundness regulation and supervision and dedicated resolution schemes that exempt them from the automatic stay of the U.S. Bankruptcy Code while imposing prompt corrective action requirements:

$>$ To reiterate, depositories are "special" because public policy has made them so; to quote Chairman Greenspan, "The real difference between banks and [other financial firms] is the difference we have made for banks." They, and they alone, 
enjoy all three privileges of the safety net: the ability to place deposits at the Fed and settle through the Fedwire Funds Service; to borrow from the Fed through the discount window; and to accept deposits insured by the Federal Deposit Insurance Corporation (FDIC) or the National Credit Union Administration (NCUA). As of end-March 2010, there were 6,772 commercial banks, 1,160 savings institutions, and 7,650 credit unions in the system, the bulk of which were community or regional institutions.

D Although their share of U.S. financial sector assets has fallen from about one-half in 1980 to close to one-fifth currently, federally insured depository institutions remain key players in many areas. Given the prevalence of originate-to-sell activities in recent years, metrics based on asset size (even with off-balance sheet assets) do not capture the totality of depository institution influence in the intermediation process. Indeed, some of the best data on "what banks do" (especially big banks) are in the noninterest income section of their financial statements, providing a window into activities ranging from bundling and servicing to trading and wealth management.

The housing GSEs, in turn, owe their privileges to their Congressional charters, which, inter alia, classify securities they issue or guarantee as "exempt securities" under the Securities Act of 1933, making them eligible for settlement through the Fedwire Securities Service, use by the Fed in open market operations, and special treatment across a range of financial regulations. The share of U.S. financial sector assets owned or guaranteed by the three housing GSEs-Fannie Mae, Freddie Mac, and the Federal Home Loan Bank system - has doubled from about one-twentieth in 1980 to over one-tenth currently, with GSE mortgage backed securities accounting for essentially all residential mortgage securitization in the system post-crisis.

- The shadow banking system. This is usually taken to include mortgage brokers and finance companies, private-label asset backed security (ABS) and asset backed commercial paper issuers, structured investment vehicles (SIVs), money market funds (MMFs), securities broker-dealers (SBDs) and futures commission merchants (FCMs), derivative product companies (DPCs), hedge funds, holding companies, and any other types of financial entities engaged in leveraged maturity transformation outside the federal financial safety net. The share of U.S. financial sector assets owned by these intermediaries has increased from about one-tenth in 1980 to about one-quarter currently:

Wholesale funded by definition, these entities form in essence a secured shortterm funding chain - through repurchase and security lending transactions - with collateral often substituting for due diligence on counterparties. Most entities in the chain are actively managed and, if they default, are subject to the automaticity of the Bankruptcy Code. MMFs must obey an investment company rule intended 
to support their stability but are not subject to daily onsite supervision of the sort applied to big wholesale-funded banks. SBDs and FCMs are subject to a comprehensive regulatory framework that includes a net liquid assets standard that protects creditors in addition to customers and is designed to minimize harm to the securities markets; the standard requires liquid assets to exceed all liabilities, i.e., that there be net capital, in order for the entity to self-liquidate without the need for a formal bankruptcy proceeding. Hedge funds are unregulated, with their investment advisors required neither to register nor to report (though many are CFTC-registered commodity pool operators).

$>$ ABS pools are, in many senses, the keystone of this shadow system, the special purpose vehicles for a technology that transforms illiquid loans into tradable (if not always traded) securities. At their pre-crisis peak, they held over one-fifteenth of U.S. financial sector assets. What makes them unique is their corporate structure: typically set up in the legal form of a trust, with no controlling shareholders and no dedicated management or staff; engineered to have carefully delimited decision-making power; owning often-opaque portfolios of selfliquidating assets that by their terms may not be actively managed; and issuing liabilities "softened" to avoid formal events of default (replaced by provisions such as "early amortization") and thus to not invoke the provisions of the Bankruptcy Code. These are the ultimate "robot" intermediaries, a reality that remains under-appreciated.

- The "real money" periphery. The third and final broad segment of the U.S. financial system consists of pension funds, mutual funds, commodity pool operators, and a raft of other types of collective investment schemes that tend to have little or no leverage and are subject to conduct-of-business rules (but not safety-and-soundness requirements) and to the Bankruptcy Code. Insurance companies arguably also belong in this broad category, because they too tend to have limited leverage (but are subject to some safety-and-soundness requirements and are resolved under state-level carve outs from the Bankruptcy Code). The asset share of this "periphery" has consistently remained at over one-third of the system since 1980 .

\section{The U.S. "regulatory perimeter" may thus be stylized as two concentric circles.}

The inner ring encircles the depositories and the housing GSEs; these firms are subject to intensive, hands-on, safety-and-soundness regulation and supervision as well as consumer protection, investor protection, and access-to-finance rules. The outer ring encircles all other types of regulated financial entities (including insurers, real money investors, and many "shadow banks"); these firms are regulated in that they must obey consumer and investor protection rules, but generally not supervised under an explicit safety-and-soundness mandate. Outside the outer ring, certain private pools of capital (e.g., DPCs and hedge funds) and instruments (e.g., credit derivatives and "144A" securities marketed only to "qualified institutional buyers," the latter including many private-label ABSs) are unregulated. 
13. Financial groups can and do straddle both these perimeters. These networks may bring together insured depositories, SBDs, FCMs, insurers, servicers, managed funds, ABS pools, DPCs, and other types of legally distinct entities under centralized enterprise-wide management, to serve one franchise, even if in ways not always visible in the formal group structure. Here one enters a world of "implicit recourse" and operational and reputational risks, where to "sponsor" an SIV or "operate" a hedge fund may rest not on beneficial ownership but on similar brand names, cross-selling, and game-theoretical commitments to provide mutual support. A large - and previously under-appreciated - share of the U.S. financial system is controlled, in one way or another, by a few key holding companies.

\section{Much of the systemic risk that has manifested during this crisis has arisen from} a few large complex conglomerates. Systemic risk may flow from one or several legal entities formally or informally within the group structure, regulated or unregulated, at home or abroad - or (as with franchise value) from the multifaceted interactions between the many moving parts. Yet, when large complex groups face funding difficulty, they tend to fail as one, at speed, with systemic repercussions. All of the most consequential U.S. crisis interventions - Bear Stearns, AIG, the Capital Purchase Program, the Temporary Liquidity Guarantee Program, etc. - thus included provisions of federal support at the ultimate holding company level. Indeed, it is this recognition of the "shared destiny" of legally separate entities within a group structure that now motivates proposals for a consolidated resolution mechanism (as discussed in the technical note on crisis management; imf.org).

\section{In the event, uninsured funding, the presumed enforcer of market discipline,} was first underpriced, then flighty - calling for better regulatory oversight. Small banks funded predominantly by federally insured deposits were more likely to suffer capital-related regulatory intervention than liquidity failure: deposit insurance worked. But large BHCs with significant short-term uninsured funding, and essentially all of the shadow banking system, proved deeply vulnerable to institutional runs. These runs were a herd response, against a backdrop of chronic data gaps - on counterparties and collateral, especially in the derivative and unregistered ABS realms - and came after a prolonged period of poorly managed risktaking. Thus not only did regulation and supervision fall short, so too did market disciplineunderscoring the need for more effective oversight going forward.

\section{U.S. CONSOLIDATED REgULATORY AND SUPERVISORY ARRANGEMENTS}

\section{Consolidated supervision is the form of financial sector oversight that best} mirrors how financial intermediaries are managed in practice. The emphasis on grouplevel interactions in a sense "peers through the corporate veil" of the de jure separation of affiliated firms, to the enterprise-wide risk management that controls them from the holding company level. Organizationally, all U.S. consolidated oversight programs have involved multiple regulators working together, with the consolidated supervisor as the nodal point, vested with critical powers to inspect any entity within the group, regulated or not. 


\section{The United States has a longstanding system of consolidated regulation and} supervision, albeit one that is highly bank-centric. In principle, all holding companies that own insured depositories, no matter how large or small, are regulated and supervised. BHCs have been under the Fed since 1956, and savings and loan holding companies (SLHCs) under the OTS (previously the Federal Home Loan Bank Board) since 1967. As of end-March 2010, there were 4,921 BHCs and 442 SLHCs in the system. Statutorily, these programs have a single-point mandate: to protect the safety and soundness of depositories within the group. Indeed, there is a "source of strength" doctrine, codifying supervisory expectations that holding companies stand ready to support their insured depository subsidiaries.

\section{There are, however, several important statutory gaps in this system, which} undermine its effectiveness. Over the years, Congress has created a labyrinth of activity restrictions, exceptions, and grandfathering arrangements. These reflect the legacy of the Glass-Steagall Acts of 1933-34, periodic regulatory changes, competitive equality and other industry concerns, and a tendency to diffuse regulatory responsibility and power. They also reflect a predilection to reform by quid pro quo, e.g., by liberalizing activity restrictions while tightening supervisory requirements, and so on. The main complexities have been:

- $\quad$ Exceptions to BHC status. Both unitary and multibank BHCs are required to limit their business to banking and activities "closely related to banking." But thrifts and certain limited-purpose banks - industrial loan companies (ILCs) chartered in only a few states, credit card banks, trust companies, and "nonbank banks," several of which themselves are products of grandfathering clauses in the Competitive Equality Banking Act of 1987 - are deemed not to be banks for the purposes of the Bank Holding Company Act (BHCA) of 1956, such that companies that own them are not BHCs and are exempt from both BHC activity restrictions and Fed oversight. All of the former "big five" U.S. investment banking groups availed of this exemption to own both FDIC-insured depositories and significant commercial interests without having to come under the consolidated regulation and supervision of the Fed.

- $\quad$ Exceptions to SLHC activity restrictions. SLHCs are subject to activity restrictions substantially similar to those applicable to BHCs. But companies that have owned a single insured thrift since before the passage of the Gramm-Leach-Bliley Act (GLBA) of 1999 are grandfathered under the preexisting provisions for unitary SLHCs and thus exempt from SLHC activity restrictions (but not OTS oversight). Several of the former "big five" investment banking groups availed of this exemption also, as did a few other large financial conglomerates (e.g., AIG and GMAC) as well as several of the largest (predominantly) nonfinancial firms in the country (e.g., GE and John Deere). These commercial firms have created regulatory and supervisory challenges for the OTS that the Fed has not faced, notably, the impracticality of imposing consolidated prudential requirements on a (predominantly) nonfinancial group. As a result, SLHCs have not been subject to any consolidated capital floor (although case-by-case capital adequacy reviews form a part of SLHC examinations). 
- The financial holding company (FHC) construct. In its famous repeal of the GlassSteagall Act of 1933, the GLBA created a new type of BHC known as the FHC, with permissible business expanded to include activities determined to be "financial in nature or incidental to such" or "complementary to a financial activity" - thus allowing the full-scope affiliation of banking, securities broker-dealing, and insurance underwriting. Only BHCs whose depository subsidiaries were all classified as "wellcapitalized" and "well-managed" could elect to become FHCs, with the Fed as the "umbrella supervisor" of all FHCs. In this role, however, the Fed was directed to defer "to the fullest extent possible" to functional regulators of nondepository affiliates (the SEC, the CFTC, and the states) and to not examine such firms unless it had "reasonable cause to believe" they posed "material risk" to insured depository affiliates. As of June 1, 2010, there were 522 FHCs.

19. The history of U.S. consolidated supervision of investment banks is even more complex. Here, the focus has been on SBDs within the group, despite the fact that there are no safety-and-soundness requirements per se for such firms: Rule 15c3-1 of the Securities Exchange Act of 1934 (the "net capital rule"), which is the key regulation governing SECregistered SBDs, merely seeks to "protect customers and other market participants from broker-dealer failures and to enable those [SBDs]...to liquidate in an orderly fashion without the need for a formal proceeding or financial assistance from the Securities Investor Protection Corporation." There were two consolidated protocols, both elective:

- The supervised investment bank holding company (SIBHC) program. The GLBA amended the Exchange Act to create a new type of broker-dealer holding company known as the SIBHC, with the proviso that such firms could not own any FDIC-insured depository, including those limited-purpose banks excluded from the definition of bank under the BHCA. Eligible holding companies could elect to become SIBHCs, with the SEC as consolidated supervisor. Analogous to the restrictions on Fed umbrella supervision of FHCs, however, the SEC was directed to defer "to the fullest extent possible" to the functional regulators (e.g., the CFTC and the states) and self-regulatory organizations (e.g., the Financial Industry Regulatory Authority and the National Futures Association) of the subsidiaries, and to restrict its examinations of the holding company and its affiliates to assessing risks that could have a "materially adverse effect" on SBDs within the group. There is only one SIBHC (Lazard).

- $\quad$ The consolidated supervised entity (CSE) program. The statutory arrangements above left two of the former "big five" U.S. investment bank holding companies (Bear and Goldman) with no consolidated host supervisor. These firms owned a trust company and a Utah-chartered ILC, respectively, but no thrift, and thus were not BHCs or SLHCs nor were eligible to become SIBHCs. When the European Parliament promulgated its Directive 2002/87/EC requiring financial conglomerates operating in the European Economic Area to have a consolidated home or host 
supervisor beginning in 2005 , the SEC responded by creating a nonstatutory regime. This, the CSE program, involved two new appendices to Rule 15c3-1 (one of which defines a value at risk-based "alternative net capital rule" with a Basel capital computation) which were intended to improve oversight of large SBDs and provide incentives for them to implement strong risk management practices; it also involved certain prudential requirements at the holding company level (including two liquidity standards). All of the "big five" U.S. investment banking groups became CSEs.

20. These arrangements underlined the difficulties of operating in an environment of multiple, overlapping regulatory regimes, with insufficient statutory guidance:

- $\quad$ Neither the SIBHC nor the CSE program imposed activity restrictions (nor do the various rules that apply directly to registered SBDs impose affiliation restrictions);

- $\quad$ The CSE program, in seeking to be a protocol tailored specifically to large investment banking groups, resorted to absolute capital norms that required participating holding companies to own at least one SBD with net capital and "tentative net capital" of not less than $\$ 500$ million and $\$ 1$ billion, respectively (and introduced a $\$ 5$ billion early warning requirement for tentative net capital) —and, as the value at risk-based alternative net capital rule provided relief, these became the binding floors;

- Whereas the alternative net capital rule is not an option for SBDs owned by SIBHCs (moot for Lazard as it has no proprietary positions), it is available to all other SBDs that meet its absolute capital thresholds and all other requirements imposed by the rule - several SBDs owned by FHCs (e.g., JPM and Citi) have opted in; and

- Whereas the CSE program recognized "the comprehensive, consolidated supervision" of the Fed and so exempted FHCs from SEC consolidated oversight, it drew no such equivalency with the supervisory regime for SLHCs - three of the "big five" investment banking groups were supervised by both the SEC and the OTS, with coordination between the two agencies being minimal, a point noted by the Government Accountability Office (GAO).

\section{OUTCOMES, REForm Proposals, AND Risks}

21. The SLHC and CSE programs were weak points during the crisis. Despite the CSE program having borrowed from well-established capital standards used by numerous regulators, the unprecedented stress of the crisis had harsh results for the CSEs: two had to be acquired by FHCs (Bear-JPM and Merrill-BoA); two converted their limited-purpose bank subsidiaries into "regular" commercial banks and so became FHCs in haste (Goldman and Morgan); and one collapsed with systemic impact (Lehman). Among the major SLHCs, one was taken over by an FHC (Countrywide-BoA); one was resolved at no cost to the Deposit Insurance Fund (WaMu-JPM); and one was bailed out (AIG). In its annual Article IV papers 
on the United States for 2007 (Country Report No. 07/253) the IMF had suggested the CSEs be reconfigured as FHCs; in the event this did occur, and the CSE program was wound up.

\section{Supervision of the risk-management processes of some of the largest, most} complex groups in the system proved a serious challenge for the OTS and the SEC. In the case of the OTS, the absence of consolidated capital requirements proved a handicap, as did the agency's small size and relatively heavy budgetary reliance on supervisory assessments paid by a few large institutions (though it bears noting that the OTS had reserves to support its operations for several years without reliance on what were the largest thrift institutions at the time). In the case of the SEC, it was a combination of a mission that stresses ex post enforcement over ex ante prudential guidance and the nonstatutory nature of the CSE program (which meant that, ultimately, the only binding enforcement action at the holding company level was disqualification from the program, with potentially serious ramifications for business conducted in Europe).

\section{Fed umbrella supervision also fell short, but remains the most robust among the} various group-level arrangements. The program stresses continuous onsite supervisory interaction with the holding company and its depository subsidiaries, with procedures laid out in an extraordinarily detailed supervisory manual. Nonetheless, revealed fragilities at a few large and diversified FHCs point to a need for more muscular oversight, especially in the form of more, and more effective, examinations of nonbank affiliates. In part, the paucity of such examinations was as directed by the "functional deference" clauses of the GLBA; but it also reflected the light touch reserved for firms outside the safety net, with the Fed concerned that overt interactions might create unwanted perceptions of federal support (a "halo effect"). As the Fed opened a tap facility to primary dealers during the crisis, however, it also began to directly examine them - a practice the FSAP team supports memorializing in law.

\section{Appropriately, therefore, U.S. reforms seek to build upon the FHC program} (Appendix Table 1). The Dodd-Frank Act leaves in place only one statutory program, with the Fed to cover holding companies that own FDIC-insured depositories as well as holding companies that own no depositories but are considered potentially systemic; the latter set of firms, as well as "large, interconnected BHCs" (with group assets of $\$ 50$ billion or more), are to be held to higher standards focused on systemic risk. The Administration had pushed for exceptions for limited-purpose banks and unitary grandfathered thrifts to be closed — with FSAP interlocutors stressing that past grandfathering arrangements were by Congressional choice, not constitutional compulsion - but here the Act merely imposes a moratorium on new charters for and ownership transfers of limited-purpose banks, pending the findings of a GAO review, and preserves unitary grandfathered thrifts. The unification of consolidated oversight at the Fed is welcome, but the exceptions are a disappointment.

25. There are risks, however, in identifying firms as systemic. Even if public designation had been avoidable (which the Act rejects), the inclusion of nonbank groups in a program populated mostly by depository institution holding companies would have been 
visible, and would have risked cementing market expectations of possible federal support for them in times of duress. Equally, the specter of large, leveraged, and interconnected conglomerates with no depository subsidiaries being left unsupervised — or of firms that are FHCs divesting such subsidiaries to escape supervision — was and is unacceptable:

- A third option might have been to cast a much wider net—say, to include all holding companies owning FDIC-insured depositories, SBDs, or FCMs - and to thereby have allowed the consolidated supervisor to concentrate on systemic groups (with or without FDIC-insured depository institution subsidiaries) while not automatically identifying them; this would have been analogous to the current system in which all BHCs are supervised by the Fed while its risk-based focus is on the largest and most complex amongst them. Such an approach, however, would potentially have brought a large number of nonsystemic nondepository holding companies under the Fed.

- A variant of this third option, then, might have been to resort to some size threshold, along the lines of that created for BHCs in the Act- those with group assets of $\$ 50$ billion or more to be automatically held to higher standards focused on systemic risk - to limit the number of nondepository groups swept into the supervisory net. Several FSAP interlocutors pointed out, however, that this too had the potential to create a self-defeating halo effect. The final legislation includes a system to designate nondepository holding companies as potentially systemic, and thence to bring them under the consolidated supervision of the Fed, subject to an appeals process. This, while perhaps not the conceptual first-best, is a good outcome.

\section{RECOMMENDATIONS AND CONCLUSION}

\section{In sum, the FSAP team's first-best recommendation for U.S. consolidated regulation and supervision was to meet the following seven goals:}

- $\quad$ To have one, and only one, federal program of consolidated regulation and supervision, grounded in statute and housed at the Fed;

- $\quad$ To cover in this program all holding companies that own one or more FDIC-insured depository institutions, regardless of charter type and without exception, plus any other financial firms deemed jointly by the Fed and FSOC to be potentially systemic;

- To give this program the dual mandate of supporting the safety and soundness of the covered groups individually and mitigating systemic risk they create collectively;

- $\quad$ To impose and require the Fed to enforce strict activity restrictions on groups covered by this program, prohibiting them from engaging in most commercial activities; 
- $\quad$ To require the Fed, through this program, to impose and enforce prudential norms at the consolidated level, with a system of mandatory supervisory actions, and to subject the largest and most interconnected of the covered groups to stricter standards;

- $\quad$ To authorize the Fed, through this program, to impose additional requirements on any regulated or unregulated subsidiary, with due attention to regulatory differences by type of firm, softening but not eliminating deference requirements; and

- $\quad$ To vest the Fed, through this program, with additional, discretionary enforcement authorities, up to and including orders to divest business lines or subsidiaries.

27. Even with several — but by no means all—of these objectives met, financial sector oversight in the United States has taken a significant step forward. Having one, and only one, program of consolidated regulation and supervision, enshrined in law and housed at the Fed, creates a robust organizational framework around which to build a new generation of prudential requirements and risk-management controls. Financial conglomerates, especially those that are large and complex, are managed at the enterprise level. Appropriately, U.S. regulatory and supervisory arrangements are continuing to adapt to reflect this.

28. Even so, difficult implementation issues lie ahead. The U.S. system has long accepted the principle of consolidated regulation and supervision of groups including federally insured depositories. Extending that system, now, to systemic nonbank consortia poses a key challenge. Not only must group-level supervision be effective, so too must be the group-level regulations that, per Chairman Greenspan, "prescribe and proscribe what must be done and what may not be done in specific areas" and so set the parameters for leverage and liquidity. Getting these right, in terms of melding rules conceived for banks with those for broker-dealers or insurers with very different business models and risk profiles, will not be easy. Similarly, on the supervisory side, the Fed will need to reallocate resources from the banking to the securities and other nonbanking operations of the groups that it oversees.

\section{Ultimately, consolidated supervision will remain but one part of the regulatory}

armory. Arguably, no matter how muscular the group-level supervisor, entity-level regulation will remain the "coal face," the place where sectoral regulatory expertise meets industry reality. Plus there will always be the tail risk of potentially systemic players slipping through the consolidated supervisory net - a standalone hedge fund perhaps, or some AIG Financial Products-type DPC. Thus the regulatory system will continue to require not just robust consolidated supervision, but also careful, case-by-case consideration of the appropriate regulatory treatment of all financial intermediaries by legal form. Although a full discussion falls well beyond the scope of this note, it is worth observing, in closing, that this is currently most relevant to certain "bank-like" entities in the shadow system. 
Appendix Table 1. United States: Key Financial Stability Proposals and Outcomes

(As of July 22, 2010)

\begin{tabular}{|c|c|c|c|c|}
\hline Issue & Administration & House & Senate & Outcome \\
\hline \multicolumn{5}{|c|}{ DEPOSITORY INSTITUTION AND HOLDING COMPANY OVERSIGHT } \\
\hline$>$ Federal thrift charter & $\begin{array}{l}\text { Eliminate federal thrift charter } \\
\text { subject to reasonable transition } \\
\text { arrangements; extend thrifts' } \\
\text { interstate branching ability to } \\
\text { all commercial banks }\end{array}$ & $\begin{array}{l}\text { Retain federal thrift charter; } \\
\text { extend thrifts' interstate } \\
\text { branching ability to all } \\
\text { commercial banks }\end{array}$ & $\begin{array}{l}\text { Eliminate federal thrift charter } \\
\text { going forward; grandfather } \\
\text { existing thrifts and their } \\
\text { interstate branches; permit } \\
\text { thrifts that become commercial } \\
\text { banks to retain their interstate } \\
\text { branch networks }\end{array}$ & $\begin{array}{l}\text { Retain federal thrift charter but } \\
\text { incentivize all thrifts to convert } \\
\text { to commercial bank charters; } \\
\text { generally extend thrifts' } \\
\text { interstate branching ability to } \\
\text { all commercial banks }\end{array}$ \\
\hline $\begin{array}{l}\text { Exceptions for unitary } \\
\text { grandfathered thrifts, ILCs, and } \\
\text { other limited-purpose banks }\end{array}$ & $\begin{array}{l}\text { Eliminate exceptions and } \\
\text { require applicable holding } \\
\text { companies to become BHCs }\end{array}$ & $\begin{array}{l}\text { Eliminate exceptions for ILCs } \\
\text { and other limited-purpose } \\
\text { banks, except credit card } \\
\text { banks, going forward; require } \\
\text { resulting new BHCs and } \\
\text { SLHCs with significant } \\
\text { commercial business to place } \\
\text { all financial activities in } \\
\text { intermediate holding } \\
\text { companies supervised by Fed }\end{array}$ & $\begin{array}{l}\text { Impose 3-year moratorium on } \\
\text { approval of applications for } \\
\text { FDIC deposit insurance by } \\
\text { ILCs and other limited-purpose } \\
\text { banks owned by commercial } \\
\text { firms and of transfers of control } \\
\text { over such entities if such } \\
\text { transfers would result in control } \\
\text { by commercial firms; require } \\
\text { study of issue by GAO; } \\
\text { preserve unitary grandfathered } \\
\text { thrift exception; Fed may } \\
\text { require SLHCs with significant } \\
\text { commercial business to place } \\
\text { all financial activities in } \\
\text { intermediate holding } \\
\text { companies supervised by Fed }\end{array}$ & $\begin{array}{l}\text { Impose 3-year moratorium on } \\
\text { approval of applications for } \\
\text { FDIC deposit insurance by } \\
\text { ILCs and other limited-purpose } \\
\text { banks owned by commercial } \\
\text { firms and of transfers of control } \\
\text { over such entities if such } \\
\text { transfers would result in control } \\
\text { by commercial firms; require } \\
\text { study of issue by GAO; } \\
\text { preserve unitary grandfathered } \\
\text { thrift exception; Fed may } \\
\text { require SLHCs with significant } \\
\text { commercial business to place } \\
\text { all financial activities in } \\
\text { intermediate holding } \\
\text { companies supervised by Fed }\end{array}$ \\
\hline $\begin{array}{l}\text { Regulation and supervision of } \\
\text { federally insured depository } \\
\text { institutions }\end{array}$ & $\begin{array}{l}\text { Merge OCC and OTS to form } \\
\text { new National Bank Supervisor } \\
\text { to oversee all federally } \\
\text { chartered banks; FDIC and } \\
\text { Fed to retain supervision of } \\
\text { state banks; NCUA unaffected }\end{array}$ & $\begin{array}{l}\text { Convert OTS into division of } \\
\text { OCC responsible for } \\
\text { supervision of federal thrifts; } \\
\text { transfer supervision of state } \\
\text { thrifts to FDIC; FDIC and Fed } \\
\text { to retain supervision of state } \\
\text { banks; NCUA unaffected }\end{array}$ & $\begin{array}{l}\text { Transfer federal and state thrift } \\
\text { supervisory functions of OTS } \\
\text { to OCC and FDIC, } \\
\text { respectively; FDIC and Fed to } \\
\text { retain supervision of state } \\
\text { banks; NCUA unaffected; } \\
\text { source of strength doctrine } \\
\text { reiterated }\end{array}$ & $\begin{array}{l}\text { Transfer federal and state thrift } \\
\text { supervisory functions of OTS } \\
\text { to OCC and FDIC, } \\
\text { respectively; FDIC and Fed to } \\
\text { retain supervision of state } \\
\text { banks; NCUA unaffected; } \\
\text { source of strength doctrine } \\
\text { reiterated }\end{array}$ \\
\hline $\begin{array}{l}>\text { Regulation and supervision of } \\
\text { holding companies }\end{array}$ & $\begin{array}{l}\text { Convert SLHCs into BHCs } \\
\text { supervised by Fed; close } \\
\text { loopholes for limited-purpose } \\
\text { banks; close SIBHC program; } \\
\text { give Fed preemption powers }\end{array}$ & $\begin{array}{l}\text { Move SLHCs to Fed; close } \\
\text { loopholes for limited-purpose } \\
\text { banks; replace SIBHC program } \\
\text { at SEC with Supervised } \\
\text { Securities Holding Company } \\
\text { (SSHC) program at Fed; soften } \\
\text { deference requirements }\end{array}$ & $\begin{array}{l}\text { BHCs and grandfathered } \\
\text { SLHCs to be supervised by } \\
\text { Fed; replace SIBHC program } \\
\text { at SEC with SSHC program at } \\
\text { Fed; soften deference } \\
\text { requirements }\end{array}$ & $\begin{array}{l}\text { Move SLHCs to Fed; replace } \\
\text { SIBHC program at SEC with } \\
\text { SSHC program at Fed; soften } \\
\text { deference requirements }\end{array}$ \\
\hline
\end{tabular}


Appendix Table 1 (continued). United States: Key Financial Stability Proposals and Outcomes

(As of July 22, 2010)

\begin{tabular}{|c|c|c|c|c|}
\hline Issue & Administration & House & Senate & Outcome \\
\hline \multicolumn{5}{|c|}{ DEPOSITORY INSTITUTION AND HOLDING COMPANY OVERSIGHT (continued) } \\
\hline $\begin{array}{l}>\text { New activity restrictions } \\
\text { ("Volcker Rule") }\end{array}$ & $\begin{array}{l}\text { Proscribe banks and bank } \\
\text { affiliates from proprietary } \\
\text { trading and investing in or } \\
\text { sponsoring hedge or private } \\
\text { equity funds }\end{array}$ & $\begin{array}{l}\text { Permit Fed to prohibit } \\
\text { proprietary trading by } \\
\text { potentially systemic financial } \\
\text { companies }\end{array}$ & $\begin{array}{l}\text { Proscribe banks, } \\
\text { grandfathered thrifts, and their } \\
\text { affiliates from proprietary } \\
\text { trading and investing in or } \\
\text { sponsoring hedge or private } \\
\text { equity funds; complex } \\
\text { exceptions, transition } \\
\text { arrangements, and forthcoming } \\
\text { studies by FSOC and GAO }\end{array}$ & $\begin{array}{l}\text { Proscribe banks, thrifts, and } \\
\text { their affiliates from proprietary } \\
\text { trading and investing in or } \\
\text { sponsoring hedge or private } \\
\text { equity funds; complex } \\
\text { exceptions, transition } \\
\text { arrangements, and forthcoming } \\
\text { studies by FSOC and GAO }\end{array}$ \\
\hline \multicolumn{5}{|c|}{ SYSTEMIC RISK MITIGATION } \\
\hline$>$ Institutional arrangements & $\begin{array}{l}\text { Create FSOC; FSOC to identify } \\
\text { systemic tier } 1 \text { FHCs (t1FHCs); } \\
\text { Fed to identify potentially } \\
\text { systemic financial market } \\
\text { utilities and payment, clearing, } \\
\text { and settlement activities; } \\
\text { FSOC and Fed authorized to } \\
\text { request and receive } \\
\text { information for financial } \\
\text { stability purposes from other } \\
\text { regulators or any financial firm }\end{array}$ & $\begin{array}{l}\text { Create FSOC; FSOC to identify } \\
\text { potentially systemic financial } \\
\text { companies; FSOC and Fed } \\
\text { authorized to request and } \\
\text { receive information for financial } \\
\text { stability purposes from other } \\
\text { regulators or any financial firm }\end{array}$ & $\begin{array}{l}\text { Create FSOC backed by Office } \\
\text { of Financial Research; FSOC } \\
\text { to identify potentially systemic } \\
\text { nonbank financial companies } \\
\text { and activities, financial market } \\
\text { utilities, and payment, clearing, } \\
\text { and settlement activities; } \\
\text { FSOC authorized to request } \\
\text { and receive information for } \\
\text { financial stability purposes } \\
\text { from other regulators or any } \\
\text { financial firm }\end{array}$ & $\begin{array}{l}\text { Create FSOC backed by Office } \\
\text { of Financial Research; FSOC } \\
\text { to identify potentially systemic } \\
\text { nonbank financial companies, } \\
\text { as well as financial market } \\
\text { utilities and payment, clearing, } \\
\text { and settlement activities; } \\
\text { FSOC authorized to request } \\
\text { and receive information for } \\
\text { financial stability purposes } \\
\text { from other regulators or any } \\
\text { financial firm }\end{array}$ \\
\hline $\begin{array}{l}\text { Systemic risk regulation and } \\
\text { supervision }\end{array}$ & $\begin{array}{l}\text { Require Fed to subject all } \\
\text { t1FHCs to heightened } \\
\text { regulation and supervision to } \\
\text { mitigate systemic risk }\end{array}$ & $\begin{array}{l}\text { Require Fed to subject all } \\
\text { identified systemic financial } \\
\text { companies to "stricter } \\
\text { standards" to mitigate systemic } \\
\text { risk }\end{array}$ & $\begin{array}{l}\text { Require Fed to subject all } \\
\text { identified systemic nonbank } \\
\text { financial companies, and any } \\
\text { large interconnected BHCs at } \\
\text { its discretion, to "enhanced } \\
\text { supervision and prudential } \\
\text { standards" to mitigate systemic } \\
\text { risk; Fed may require } \\
\text { potentially systemic nonbank } \\
\text { financial companies with } \\
\text { significant commercial } \\
\text { business to place all financial } \\
\text { activities in intermediate } \\
\text { holding companies }\end{array}$ & $\begin{array}{l}\text { Require Fed to subject all } \\
\text { identified systemic nonbank } \\
\text { financial companies, and any } \\
\text { large interconnected BHCs at } \\
\text { its discretion (must include all } \\
\text { BHCs with assets } \geq \$ 50 \text { bn), to } \\
\text { "enhanced supervision and } \\
\text { prudential standards" to } \\
\text { mitigate systemic risk; Fed may } \\
\text { require potentially systemic } \\
\text { nonbank financial companies } \\
\text { with significant commercial } \\
\text { business to place all financial } \\
\text { activities in intermediate } \\
\text { holding companies }\end{array}$ \\
\hline
\end{tabular}


Appendix Table 1 (continued). United States: Key Financial Stability Proposals and Outcomes

(As of July 22, 2010)

\begin{tabular}{|c|c|c|c|c|}
\hline Issue & Administration & House & Senate & Outcome \\
\hline \multicolumn{5}{|c|}{ SYSTEMIC RISK MITIGATION (continued) } \\
\hline$>$ Break-up powers & $>$ Silent & $\begin{array}{l}\text { Authorize Fed to require } \\
\text { divestitures by identified } \\
\text { systemic financial companies if } \\
\text { significantly undercapitalized; } \\
\text { or authorize FSOC to require } \\
\text { divestitures if it determines, } \\
\text { and Treasury Secretary } \\
\text { concurs (for divestitures } \\
\geq \$ 10 \text { bn), that they pose } \\
\text { "grave threat" to financial } \\
\text { stability }\end{array}$ & $\begin{array}{l}\text { Authorize Fed to require } \\
\text { divestitures by identified } \\
\text { systemic nonbank financial } \\
\text { companies and large } \\
\text { interconnected BHCs (with } \\
\text { assets } \geq \$ 50 \text { bn) if "at later } \\
\text { stages of financial decline" or if } \\
\text { it determines, and FSOC } \\
\text { concurs, that they pose "grave } \\
\text { threat" to financial stability; } \\
\text { authorize FDIC and Fed jointly } \\
\text { to require divestitures in the } \\
\text { event of persistent deficiencies } \\
\text { in mandatory resolution plans }\end{array}$ & $\begin{array}{l}\text { Authorize Fed to require } \\
\text { divestitures by identified } \\
\text { systemic nonbank financial } \\
\text { companies and large } \\
\text { interconnected BHCs if "at later } \\
\text { stages of financial decline" or if } \\
\text { it determines, and FSOC } \\
\text { concurs, that they pose "grave } \\
\text { threat" to financial stability; } \\
\text { authorize FDIC and Fed jointly } \\
\text { to require divestitures in the } \\
\text { event of persistent deficiencies } \\
\text { in mandatory resolution plans }\end{array}$ \\
\hline $\begin{array}{l}\text { Payment, clearing, and } \\
\text { settlement system oversight }\end{array}$ & $\begin{array}{l}\text { Subject Fed-designated } \\
\text { systemic utilities to risk } \\
\text { management standards } \\
\text { prescribed by Fed and (primary } \\
\text { or back-up) supervision by } \\
\text { Fed; those not chartered as } \\
\text { banks may be granted access } \\
\text { to Fedwire and, in extremis, to } \\
\text { the discount window }\end{array}$ & $>$ Silent & $\begin{array}{l}\text { Subject FSOC-designated } \\
\text { systemic utilities to heightened } \\
\text { and uniform risk management } \\
\text { standards and (primary or } \\
\text { back-up) supervision by Fed; } \\
\text { those not chartered as banks } \\
\text { may be granted access to } \\
\text { Fedwire and, in extremis, to } \\
\text { the discount window }\end{array}$ & $\begin{array}{l}\text { Subject FSOC-designated } \\
\text { systemic utilities to heightened } \\
\text { and uniform risk management } \\
\text { standards and (primary or } \\
\text { back-up) supervision by Fed; } \\
\text { those not chartered as banks } \\
\text { may be granted access to } \\
\text { Fedwire and, in extremis, to } \\
\text { the discount window }\end{array}$ \\
\hline \multicolumn{5}{|c|}{ RESOLUTION } \\
\hline $\begin{array}{l}\text { Coverage of special resolution } \\
\text { mechanism }\end{array}$ & $\begin{array}{l}\text { Apply to any BHC, including } \\
\text { any t1FHC, whose failure } \\
\text { would have serious adverse } \\
\text { effects on the financial system } \\
\text { or the economy; invoke using } \\
\text { procedures modeled on } \\
\text { systemic risk exception }\end{array}$ & $\begin{array}{l}\text { Apply to any financial company } \\
\text { not already under a dedicated } \\
\text { carve-out from the Bankruptcy } \\
\text { Code, including any BHC or } \\
\text { identified systemic financial } \\
\text { company whose failure would } \\
\text { be systemically destabilizing; } \\
\text { invoke using procedures } \\
\text { modeled on systemic risk } \\
\text { exception }\end{array}$ & $\begin{array}{l}\text { Apply to any financial company } \\
\text { not already under a dedicated } \\
\text { carve-out from the Bankruptcy } \\
\text { Code, including any BHC or } \\
\text { identified systemic nonbank } \\
\text { financial company, whose } \\
\text { failure would be systemically } \\
\text { destabilizing; invoke using } \\
\text { procedures modeled on } \\
\text { systemic risk exception, } \\
\text { subject to approval of U.S. } \\
\text { District Court for the District of } \\
\text { Columbia }\end{array}$ & $\begin{array}{l}\text { Apply to any financial company } \\
\text { not already under a dedicated } \\
\text { carve-out from the Bankruptcy } \\
\text { Code, including any BHC or } \\
\text { identified systemic nonbank } \\
\text { financial company, whose } \\
\text { failure would be systemically } \\
\text { destabilizing; invoke using } \\
\text { procedures modeled on } \\
\text { systemic risk exception, } \\
\text { subject to approval of U.S. } \\
\text { District Court for the District of } \\
\text { Columbia }\end{array}$ \\
\hline
\end{tabular}


Appendix Table 1 (continued). United States: Key Financial Stability Proposals and Outcomes

(As of July 22, 2010)

\begin{tabular}{|c|c|c|c|c|}
\hline Issue & Administration & House & Senate & Outcome \\
\hline \multicolumn{5}{|c|}{ RESOLUTION (continued) } \\
\hline $\begin{array}{l}\text { Resolution agency, objectives, } \\
\text { and tools }\end{array}$ & $\begin{array}{l}\text { Authorize Treasury to appoint } \\
\text { FDIC as receiver or } \\
\text { conservator (or SEC if largest } \\
\text { subsidiary is a broker-dealer) } \\
\text { with authority to replace } \\
\text { management, transfer qualified } \\
\text { financial contracts (QFCs), } \\
\text { repudiate contracts, provide } \\
\text { up-front financial assistance, } \\
\text { and establish bridge holding } \\
\text { company }\end{array}$ & $\begin{array}{l}\text { Authorize Treasury Secretary } \\
\text { to appoint FDIC as receiver but } \\
\text { not conservator for up to } \\
3 \text { years with authority to } \\
\text { replace management, transfer } \\
\text { QFCs, repudiate contracts, } \\
\text { provide up-front financial } \\
\text { assistance, and establish } \\
\text { bridge financial company for up } \\
\text { to } 5 \text { years }\end{array}$ & $\begin{array}{l}\text { Authorize Treasury Secretary } \\
\text { to appoint FDIC as receiver but } \\
\text { not conservator for up to } \\
5 \text { years with authority to } \\
\text { replace management, transfer } \\
\text { QFCs, repudiate contracts, } \\
\text { provide up-front financial } \\
\text { assistance, and establish } \\
\text { bridge financial company for up } \\
\text { to } 5 \text { years }\end{array}$ & $\begin{array}{l}\text { Authorize Treasury Secretary } \\
\text { to appoint FDIC as receiver but } \\
\text { not conservator for up to } \\
5 \text { years with authority to } \\
\text { replace management, transfer } \\
\text { QFCs, repudiate contracts, } \\
\text { provide up-front financial } \\
\text { assistance, and establish } \\
\text { bridge financial company for up } \\
\text { to } 5 \text { years }\end{array}$ \\
\hline$>$ Resolution funding & $\begin{array}{l}\text { Authorize FDIC (or SEC) to } \\
\text { borrow from Treasury } \\
\text { unconstrained by federal debt } \\
\text { ceiling; excess liquidation costs } \\
\text { to be covered through ex ante } \\
\text { or ex post assessments on } \\
\text { uninsured liabilities of BHCs }\end{array}$ & $\begin{array}{l}\text { Authorize FDIC to borrow from } \\
\text { Treasury } \leq \$ 150 \text { bn (or } \\
\leq \$ 200 \text { bn subject to approval } \\
\text { by Congress); liquidation costs } \\
\text { to be borne by shareholders } \\
\text { and unsecured creditors; } \\
\text { excess liquidation costs to be } \\
\text { covered through ex ante risk- } \\
\text { based assessments on } \\
\text { financial companies with } \\
\text { assets } \geq \$ 50 \text { bn (or hedge } \\
\text { funds } \geq \$ 10 \text { bn) until fund } \\
\text { balance reaches } \$ 150 \text { bn }\end{array}$ & $\begin{array}{l}\text { Authorize FDIC to borrow from } \\
\text { Treasury } \leq 10 \text { percent of book } \\
\text { value plus } 90 \text { percent of fair } \\
\text { value of aggregate assets of } \\
\text { firms under special } \\
\text { receivership; liquidation costs } \\
\text { to be borne by shareholders } \\
\text { and unsecured creditors; } \\
\text { excess liquidation costs to be } \\
\text { covered through ex post risk- } \\
\text { based assessments on BHCs } \\
\text { with assets } \geq \$ 50 \text { bn and } \\
\text { identified systemic nonbank } \\
\text { financial companies }\end{array}$ & $\begin{array}{l}\text { Authorize FDIC to borrow from } \\
\text { Treasury } \leq 10 \text { percent of book } \\
\text { value plus } 90 \text { percent of fair } \\
\text { value of aggregate assets of } \\
\text { firms under special } \\
\text { receivership; liquidation costs } \\
\text { to be borne by shareholders } \\
\text { and unsecured creditors; } \\
\text { excess liquidation costs to be } \\
\text { covered through ex post risk- } \\
\text { based assessments on BHCs } \\
\text { with assets } \geq \$ 50 \text { bn and } \\
\text { identified systemic nonbank } \\
\text { financial companies }\end{array}$ \\
\hline$>$ Resolution plans & $\begin{array}{l}\text { Require t1FHCs to periodically } \\
\text { submit rapid and orderly } \\
\text { resolution plans to Fed }\end{array}$ & $\begin{array}{l}\text { Require identified systemic } \\
\text { financial companies to } \\
\text { periodically submit rapid and } \\
\text { orderly resolution plans to } \\
\text { FDIC and Fed }\end{array}$ & $\begin{array}{l}\text { Require identified systemic } \\
\text { nonbank financial companies } \\
\text { and large interconnected BHCs } \\
\text { (with assets } \geq \$ 50 \text { bn) to } \\
\text { periodically submit rapid and } \\
\text { orderly resolution plans to } \\
\text { FDIC, Fed, and FSOC }\end{array}$ & $\begin{array}{l}\text { Require identified systemic } \\
\text { nonbank financial companies } \\
\text { and large interconnected BHCs } \\
\text { (with assets } \geq \$ 50 \text { bn) to } \\
\text { periodically submit rapid and } \\
\text { orderly resolution plans to } \\
\text { FDIC, Fed, and FSOC }\end{array}$ \\
\hline
\end{tabular}


Appendix Table 1 (concluded). United States: Key Financial Stability Proposals and Outcomes

(As of July 22, 2010)

\begin{tabular}{|c|c|c|c|c|}
\hline Issue & Administration & House & Senate & Outcome \\
\hline \multicolumn{5}{|c|}{ EMERGENCY FINANCIAL STABILIZATION } \\
\hline $\begin{array}{l}\text { Fed credit accommodations } \\
\text { under Section 13(3) of Federal } \\
\text { Reserve Act }\end{array}$ & $\begin{array}{l}\text { Require ex ante written } \\
\text { approval by Treasury } \\
\text { Secretary }\end{array}$ & $\begin{array}{l}\text { Limit to broadly available } \\
\text { liquidity programs for } \\
\text { individuals, partnerships, or } \\
\text { corporations, with } \geq 99 \text { percent } \\
\text { probability of repayment, after } \\
\text { determination of "liquidity } \\
\text { event" by FSOC and consent } \\
\text { by Treasury Secretary (in } \\
\text { consultation with President); } \\
\text { may not exceed } \$ 4 \text { trn; may be } \\
\text { halted by Congress }\end{array}$ & $\begin{array}{l}\text { Limit to broadly available } \\
\text { liquidity programs for solvent } \\
\text { nonbank financial firms, } \\
\text { subject to ex ante approval by } \\
\text { Treasury Secretary and ex } \\
\text { post reporting to Congressional } \\
\text { committees and GAO audit; } \\
\text { Fed to develop guiding } \\
\text { regulations in consultation with } \\
\text { Treasury Secretary; no cap; no } \\
\text { veto by Congress }\end{array}$ & $\begin{array}{l}\text { Limit to broadly available } \\
\text { liquidity programs for solvent } \\
\text { nonbank financial firms, } \\
\text { subject to ex ante approval by } \\
\text { Treasury Secretary and ex } \\
\text { post reporting to Congressional } \\
\text { committees and GAO audit; } \\
\text { Fed to develop guiding } \\
\text { regulations in consultation with } \\
\text { Treasury Secretary; no cap; no } \\
\text { veto by Congress }\end{array}$ \\
\hline$>$ FDIC guarantee authority & $\begin{array}{l}\text { Authorize assistance to open } \\
\text { (including failing) financial } \\
\text { institutions, including through } \\
\text { loans, asset purchases, } \\
\text { guarantees, and equity } \\
\text { investments }\end{array}$ & $\begin{array}{l}\text { Limit to broadly available } \\
\text { guarantees on obligations of } \\
\text { solvent FDIC-insured } \\
\text { depositories and their holding } \\
\text { companies, after determination } \\
\text { of "liquidity event" by FSOC } \\
\text { and consent by Treasury } \\
\text { Secretary (in consultation with } \\
\text { President); Congress to } \\
\text { approve amounts }>\$ 500 \text { bn; } \\
\text { FDIC to develop guiding } \\
\text { regulations in consultation with } \\
\text { FSOC and Treasury Secretary; } \\
\text { all of above to sunset at end- } \\
2013\end{array}$ & $\begin{array}{l}\text { Limit to broadly available } \\
\text { guarantees on obligations of } \\
\text { solvent FDIC-insured } \\
\text { depositories and their holding } \\
\text { companies, after joint } \\
\text { determination of "liquidity } \\
\text { event" by Fed and FDIC upon } \\
\text { request by Treasury Secretary; } \\
\text { Treasury Secretary to } \\
\text { recommend maximum amount } \\
\text { to President, Congress to } \\
\text { approve; FDIC to develop } \\
\text { guiding regulations in } \\
\text { consultation with Treasury } \\
\text { Secretary; no sunset }\end{array}$ & $\begin{array}{l}\text { Limit to broadly available } \\
\text { guarantees on obligations of } \\
\text { solvent FDIC-insured } \\
\text { depositories and their holding } \\
\text { companies, after joint } \\
\text { determination of "liquidity } \\
\text { event" by Fed and FDIC upon } \\
\text { request byTreasury Secretary; } \\
\text { Treasury Secretary to } \\
\text { recommend maximum amount } \\
\text { to President, Congress to } \\
\text { approve; FDIC to develop } \\
\text { guiding regulations in } \\
\text { consultation with Treasury } \\
\text { Secretary; no sunset }\end{array}$ \\
\hline
\end{tabular}

Sources: Administration proposals: U.S. Department of the Treasury, 2009, "Financial Regulatory Reform: A New Foundation," white paper, June 17; and The White House, Office of the Press Secretary, 2010, "President Obama Calls for New Restrictions on Size and Scope of Financial Institutions to Rein in Excesses and Protect Taxpayers," statements and

releases, January 21. House-passed bill: The Library of Congress, 2010, "Wall Street Reform and Consumer Protection Act of 2009," H.R. 4173.RFS, Referred in Senate, January 20. Senate-passed substitute: The Library of Congress, 2010, "Restoring American Financial Stability Act of 2010," H.R. 4173.PP, Public Print, May 27. Final House- and Senate-passed bill: The Library of Congress, 2010, "Dodd-Frank Wall Street Reform and Consumer Protection Act of 2010," H.R. 4173.ENR, Enrolled Bill, July 15. 